\title{
THE ROLE OF JEWISH WOMEN IN MEDIEVAL ENGLAND (PRESIDENTIAL ADDRESS)
}

\section{by BARRIE DOBSON}

I $\mathrm{N}$ devoting its attention to the relationship between Christianity and Judaism, the Ecclesiastical History Society has self-evidently addressed a theme as fundamental as it is often distressing to the practitioners of both religions. For many historians of the English Church, as for many of this Society's members themselves, that relationship presents the additional irony that it would have been almost impossible actually to encounter a Jew in this country during those three centuries which tend to interest them most. As it is, Edward l's expulsion of all his Jewish subjects from his realm on 18 July 1290 ('without any hope of ever remaining there') ${ }^{1}$ not only aborted a still inconclusive experiment in religious co-existence, but for centuries relegated the lives of the Jews and Jewesses of Anglo-Norman and Plantagenet England to the obscurity of the historically irrelevant. No longer in I99I does that seem at all so obvious; and one supposes that nothing would have surprised Henry III and Edward I more than that their treatment of the Jewish minority within their realm should now of ten seem more 'relevant' to the churches of the modern world than any other feature of their respective reigns. For that reason, above all, there must be every prospect that the relationship between Jews and Christians in twelfth- and thirteenth-century England will soon be subjected to more detailed analysis than ever before. ${ }^{2}$ Nor, for similar reasons, has it ever been quite so obvious as it is today that the study of medieval Anglo-Jewry is too important to remain the exclusive preserve of historians who are themselves Jews.

Nowhere are such developments likely to have more of an impact than upon the obscurities of the role played by Jewish women within their own communities and within English urban society as a whole during the century and more before the expulsion of 1290 . For there can indeed be

1 Chronicle of Bury St Edmunds, $1212-1301$, cd. A. Gransden (London, 1964), p. 61.

2 See, e.g., R. Stacey, 'Recent work on medieval English Jewry', Jewish History, 2 ( 1987 ), pp. 6 i72; J. Hillaby, 'The Worcester Jewry, i i 58-1290: portrait of a lost community', Transactions of the Worcestershire Archaeological Society, ser. 3, 12 (1990), pp. 73-122; R. Mundill, 'Anglo-Jewry under Edward I: credit agents and their clients', TJHSE, 3 I (1988-90), pp. I-2I. 
no doubt that in practice the female members of medieval Jewish households were of more critical importance to the relations between Christians and Jews than has ever been allowed: in thirteenth-century England at least, the Jewish woman is nearly always revealed at the most personal, painful, and significant interface between the two religions. It is therefore not a little surprising that whereas all sorts and conditions of medieval Christian women have been studied with ever-increasing intensity in recent years, the Jewish wife, widow, and daughter of medieval England still linger in comparative obscurity. Such neglect is no longer likely to persist indefinitely, above all, perhaps, because the Jewish woman seems to offer so interesting a non-Christian alternative 'role model' for the many historians now intent on recapturing the life of the medieval female within and outside her family. For very obvious reasons, French and German rabbinical opinion in the twelfth and thirteenth centuries usually projects a very different, more sensitive, and even more respectful image of the female sex than do the pronouncements of contemporary Christian popes and bishops. ${ }^{3}$ Such an image can, of course, itself be deceptive; and this paper will suggest that one of the hazards facing the historian of the medieval Jewess may be the temptation to idealize her just because she is a Jewess. Similarly, it can be dangerously easy to exaggerate the very real contrasts there inevitably were between the material and emotional values espoused by medieval Jewish and Christian women in thirteenth-century England. In both cases their male contemporaries almost always-and altogether predictably-laid greatest public emphasis upon the ideal of female domesticity and the truism that 'the functions of women were in the home."4

However, there can equally be no doubt that highly important as well as extremely complex differences existed berween both the real existences and the contemporary stereotypes of medieval Jewish and Gentile women.

${ }^{3}$ I. Abrahams, Jewish Life in the Middle Ages (London, 1896), pp. I1 3-2 10; L. Rabinowitz, The Social Life of the Jews of Northern France in the Twelfth to Fourteenth Centuries as reflected in the Rabbinical Literature of the Period (London, 1938), pp. 137-65; I. A. Agus, Urban Civilisation in Pre-Crusade Europe: a Study of Organised Town-Life in Northwestern Europe during the Tenth and Eleventh Centuries based on the Responsa Literature, 2 vols (Leiden, 1965), 2, pp. $554-690$.

+ Rabinowitz, Social Life, pp. 164-s. It might still be argued that most Jewish women of the eleventh and twelfth centuries seem to have escaped the so-called 'family revolution' which allegedly did so much to depress the status of prominent Christian women in north-western Europe at this period: see F. and J. Gies, Marriage and Family in the Middle Ages (New York, 1989), pp. 121-32; G. Duby, The Knight, the Lady and the Priest: the Making of Modern Marriage in Medieval France (New York, 1983); C. N. L. Brooke, The Medieval Idea of Marriage (Oxford, 1989); and (for a very different perspective) P. Biller, 'The Common Woman in the Western Church in the thirteenth and early fourteenth centuries', $\mathrm{SCH}, 27$ (1990), pp. 127-57. 


\section{Jewish Women in Medieval England}

Among their male partners, it was self-evidently much more true of the latter than the former that 'most of those who wrote explicitly about women did so to denigrate them, and most of those who wrote for other

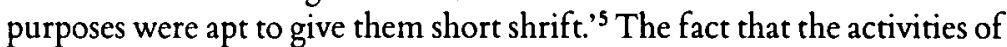
thirteenth-century English Jewesses are frequently more fully and more favourably documented than those of their Christian counterparts was, in fact, the most significant revelation of the late Reverend Michael Adler's pioneering paper on 'The Jewish Woman in Medieval England', originally delivered as a Presidential Address to the Jewish Historical Society of England in November 1934. In that lecture, still the only substantial study of the topic, Adler was at pains to point out that 'the lives of English Jewish women are recorded in the archives of the period in fuller detail than in any other country. ${ }^{6}$ Nearly sixty years later, such an opportunity should surely no longer be neglected, even if this lecture can do no more than attempt to provide a few fleeting insights into the role of women in the more substantial Jewish households and financial businesses of thirteenth-century England. Even more fleeting, but all the more precious for that reason, are the occasional glimpses afforded by the governmental records of the reigns of Henry III and Edward I into the Jewish woman's relations with her Christian neighbours, as well as her reactions to the increasing threat of deliberate persecution during the years immediately before the final catastrophe of 1290 . Neither of these last two issues was of great concern to Adler, who had indeed no particularly general thesis upon the role of the Jewish woman in medieval England to advance. However, Adler's most important conclusion-the 'unequalled' importance of the Jewish woman 'within and without the community'-can certainly still afford to stand.' More important still, perhaps, Adler was the first scholar to reveal that when the full history of the Jewish woman in medieval England comes to be written, it will have to be based in most of its essentials on the tantalizingly incomplete fragments of minor narrative to be extracted from the plea rolls of the Exchequer of the Jews. ${ }^{8}$

It accordingly seems appropriate to approach the experience of at least

3 J. T. Rosenthal, ed, Medieval Women and the Sources of Medieval History (Arlanta, Georgia, 1990), p. viii. For a pioneering attempt to expose 'the contradictory ideas about women formulated during the Middle Ages', see E. Power, Medieval Women (Cambridge, 1975), pp. 9-34.

' M. Adler, 'The Jewish Woman in Medieval England', in Jews of Medieval England (London, 1939), p. 39.

7 Ibid., pp. 17-18.

8 The long-awaited fifth volume in the series of Calendars of the Plea Rolls of the Exchequer of the Jews, inaugurated by J. M. Rigg in 190 s [hereafter Cal. Jewish Plea Rolls], appeared too lare to be consulted for the purposes of this paper. 
some Jewish women in medieval England by means of such a fragmentary narrative, a very painful narrative, in fact, but one which has at least the incidental value of demonstrating that Jewish women were quite as capable of conflict with one another as they were with the wives of Christian townsmen. This is a story, moreover, which has the additional interest of starting at the door of one of those fundamental, if obscure, centres of Jewish life in medieval England, the synagogue in the high street of Warwick, then the site of the most substantial English Jewish community and Jewish archa in the Midlands, and, as such, the greatest source of credit available in the region. ${ }^{9}$ A little after noon on Monday I9 September 1244 Bessa, wife of Elias, was walking out of the door of that synagogue (ad janitum scole) when she encountered, apparently by chance, another Warwick Jew, Leo of Deubelen, who was accompanied by a positive bevy of his womenfolk-his wife Henna, his two daughters, Ancerra and Sigge, and his sister Muriel. According to Bessa's version of what followed, Leo violently kicked her (percussit eam cum pede) inside the doorway of the synagogue, so that she fell there in a fit, as if dead. Nevertheless, all four female members of Leo's family then proceeded 'to drag the said Bessa out of the doorway by the hair and beat her and so illtreated her that when she was brought home she miscarried of her infant; but the child was as yet too young for its sex to be distinguished.' According to testimony later submitted on her behalf by her husband, Elias of Warwick, injury was then added to dire insult when the defenceless Bessa was robbed by Leo and his family of a gold buckle and eight of her gold rings, to the value of ten marks. ${ }^{10}$

This most detailed surviving account of the ill-treatment of a medieval English Jewish woman by other Jewish women was not, however, allowed to go unchallenged. The detailed charges brought by Elias in his subsequent appeal before the justices of the Jews were systematically denied by Leo's family, partly on the grounds that Elias had not been an eyewitness of the alleged assault, and partly because Bessa was still alive and might have sued, but did not do so. More generally, Leo and his relatives accused Bessa of complete falsehood: according to their version of events, the latter had herself begun the affray by assaulting members of Leo's family in the Warwick high street and then by gnawing at the nose

9 PRO, E. 9/4, memb. 4 d; J. M. Rigg, ed., Select Pleas, Starts and other Records from the Rolls of the Exchequer of the Jews, 1220-1284 - Selden Sociery, is (London, 1902) [hertafter Rigg, Select Pleas], pp. 11-12.

${ }^{10}$ Cal. Jewish Plea Rolls, 1, pp. 103-4; Adler, 'Jewish Woman', p. 36. 


\section{Jewish Women in Medieval England}

and ears of his daughter Ancerra. Even the alleged miscarriage (horribile dictu) was no miscarriage at all because the blood on Bessa's body and bed had, in fact, been animal blood deliberately placed there to deceive. Whatever the exact circumstances of this unsavoury assault, the justices of the Jews and the jurors at the Warwickshire County Court, to which the case was referred, found it possible to come to a decision at some speed. Bessa disappears from the records for ever, her husband, Elias, was fined for making a false charge of robbery, while Leo and all his womenfolk ('his wife and his two daughters and his sister and his household') were first imprisoned and then forced to 'abjure the town of Warwick, thence to depart with all their chattels and never to return'. So might an internecine quarrel between families, and especially between their female members, affect the crucial-and still mysterious-issue of Jewish migration within the English realm. ${ }^{11}$

No doubt so vivid and sanguinary a conflict demands an anthropologist, perhaps even a Lévi-Strauss, rather than a historian for its full elucidation. More prosaically and predictably, the real or alleged assault on Bessa of Warwick serves to illustrate particularly well many of the themes and problems which characterize the place of Jewish women in thirteenth-century English society. In the first place, the Jewish wife and daughter could freely walk the streets of provincial towns; and it would obviously be unwise to assume that they usually lived either the secluded or the gentle life advocated in Hebrew religious literature. In fact, and not too surprisingly, female involvement in acts of violence and occasionally even of murder against fellow Jews was a not uncommon feature of their communities, subjected as the latter were to sustained psychological pressure from the Christian population around them. ${ }^{12}$ Moreover, as the case of Bessa of Warwick demonstrates equally well, our knowledge of

"PRO, E. $9 / 4$, memb. 4 d; Rigg, Select Pleas, pp. I I-12. No member of the Jewish community at Warwick in 1244 can have been particularly secure: only ten years earlier all their predecessors had been temporarily expelled from the town and county there: see $\mathrm{C}$. Roth, $A$ History of the Jews in England, 3 rd edn (Oxford, 1978), p. 58.

${ }^{12}$ For several examples of murder-allegations brought against Jewish women in Bristol and Oxford, see Adler, 'Jewish Woman', pp. 34-5. More intriguing is the case of Milo or Meir of York, who accused three Christians of killing his wife, a crime he apparently commitred himself because of his affair ('rem') with Belina, another Jewess: Curia Regis Rolls of the Reigns of Richard I, John and Henry III, I6 vols (London, 1922-79), 5, p. 256; R. B. Dobson, The Jews of Medieval York and the Massacre of March 1 190 - Borthwick Papers, no. 45 (York, 1974), p. 39. No doubt much more common (but much less of ten recorded) is the experience which befell an Exeter Jewess named Henna, who had stones thrown at her in South Street by a boy attending the city school: Unity and Variety, a History of the Church in Devon and Cormwall, ed. N. Orme (Exeter, 1991), P. 47. 


\section{BARRIE DOBSON}

conflicts between Jews, let alone between Jews and Christians, is utterly dependent on the records compiled and preserved by Christian clerks. In the absence of responsa and other forms of Hebraic literary source material available on the other side of the Channel, the historian of the Jewish woman in medieval England has accordingly little alternative but to approach his subject through the clinically dispassionate or even hostile eyes of the Angevin and Plantagenet bureaucracy. To that extent, she was both less and more fortunate than her Christian counterpart: at times, as will be seen, more liberated than the latter, she is most often-in the nature of things-to be observed at times of private and public (especially financial) distress. Within what the late Dr Cecil Roth quite properly categorized as the 'artificial' world of medieval Anglo-Jewry, it may well be that the role of the Jewish woman has a variety of admirable moral qualities to display, but only at the cost of tragic risks to be run. ${ }^{13}$

However, the most important moral to emerge from the assault on Bessa, wife of Elias, is obvious enough. Whatever the precise reasons for the violence at Warwick in 1244 , both she and her adversary, Ancerra, were clearly the victims less of a personal than of a family conflict. Moreover, this proved a conflict which could only be properly resolved by the exiling of one of the two families at serious and violent odds with one another from Warwick itself. It needs no urging that the lives of Jewish women in thirteenth-century England were quite as inextricably part of the history of their own households as were those of their Christian neighbours. ${ }^{14}$ It is accordingly all the more regrettable that it proves so difficult, even in the best documented provincial Jewries of thirteenthcentury England, to estimate the total number of such households in any one Jewish community. As is well known, demographic uncertainty is the single most frustrating problem facing the historian of medieval AngloJewry. Unfortunately, the only surviving national statistics for the size of the English Jewry as a whole derive from the accounts of the annual polltax, or chevage, levied on approximately I, I 50 Jewish males and females (over the age of twelve) as late as the very early $1280{ }^{15} .{ }^{15}$ Half a century

${ }^{13}$ Roth, History of Jews, p. 91. If anything, however, the persecution and insecurity undergone by Jewish women in northern France during the late thirteenth century was even more prorracted than in England: R. Chazan, Medieval Jewry in Northern France: a Political and Social History (Baltimore, 1973), pp. 154-205.

14 Cf. B. A. Hanawalt, The Ties that Bound: Peasant Families in Medieval England (Oxford, 1986), pp. 107-55; C. M. Barron, 'The golden age of women in medieval London', Reading Medieval Studies, is (1989), pp. 35-58.

is PRO, E. IOI/249/24, discussed in R. B. Dobson, 'The decline and expulsion of the medieval Jews of York', TJHSE, 26 (r979), p. 51 , 11. 78 . 


\section{Jewish Women in Medieval England}

earlier, during the reign of Henry III, the total number of Jews in England was certainly higher, but perhaps only in the order of the 4,000 to 5,000 souls once suggested (admittedly on no very certain evidence) by the late Dr V. D. Lipman. ${ }^{16}$ Slightly more valuable is the latter's better informed guess that 'the Jewish population of Norwich is unlikely ever to have been much above 200': such an estimate is not only more persuasive in itself, but seems likely to have been true of more or less all Jewish communities in thirteenth-century England, with the obvious exception of London. ${ }^{17}$ It seems more likely than not that all the adult women of a provincial English Jewry could have been gathered together within their one local synagogue.

Admittedly these calculations, if such they can be called, are open to the criticism that many of the poorer Jewish families in English provincial centres may well have escaped documentation altogether, so creating what might be a seriously distorted impression of the size and social structure of medieval Anglo-Jewry as a whole. Nowhere, moreover, is such distortion more likely to confuse than in the case of the Jewish woman. For very familiar reasons, Jewesses identifiable in extant financial and legal records tend to be heavily weighted towards that minority of women (and especially widows) who conducted business by written contract, secondly, towards women whose inheritances caused envy and dispute, and finally, towards women who committed, or were alleged to have committed, felonies and lesser crimes. It follows that most medieval English Jewish wives and mothers-much as can be known about the exceptions-must always be as impossible to identify as they are to count. To take only one example, perhaps the most important document left to posterity by the archa of the medieval Cambridge Jewry is a list of the bonds of deposit there in or about 1240 by forty-seven named Jews: of those forty-seven names, only four are those of women, one a widow and three others designated as daughters. ${ }^{18}$ Among the almost innumerable surviving lists of loans and tallages owed to and by individual members of the thirteenth-century English Jewry, it is very rare indeed to encounter

16 V. D. Lipman, The Jews of Medieval Norwich (London, 1967), pp. 36-8; Roth, History of Jews, pp. $91,93,276$.

17 Lipman, Jews of Medieval Norwich, p. 38. According to Ephraim Bonn, the most reliable authority for the atrocity, approximately 150 Jewish men and women lost their lives at Clifford's Tower during the (nor necessarily toral) massacre of the York Jews in March I 190 (Dobson, Jews of Medieval York, p. Is).

14 PRO, E. IOI , 249/3; printed in H. P. Stokes, Studies in Anglo-jewish History (Edinburgh, 1913 ). pp. $252-75$. 


\section{BARRIE DOBSON}

an instance where the names of males do not surpass those of females by at least a ratio of four or five to one. The same ascendancy of male over female names is still absolutely evident to the very end, when in I 290 and I29I the royal sheriffs were systematically stripping the assets of the last members of the medieval English Jewry. ${ }^{19}$

In a situation of such demographic insecurity, not too unfamiliar, of course, to students of thirteenth-century Christian women, it is at least reassuring that a little, if only a little, is beginning to be known about the composition of the Jewish family itself. Some light on male-female sex ratios is about to be afforded by the forthcoming report on the 497 Jewish skeletons examined and studied in the aftermath of the York Archaeological Trust's excavation at Jewbury, York, in I 982-3. Not all these skeletons proved easy to sex; but provisional findings suggest the presence in this cemetery, probably used continuously by the York Jews from about I I 80 to about I 290 , of the remains of I I females ( 31.7 per cent), as compared with 163 males ( 34.2 per cent) and 141 children (29.6 per cent). ${ }^{20}$ However, a fuller reconstitution of some of the betterdocumented urban Jewish households of medieval England still awaits the systematic analysis of first and second personal Jewish names-no easy matter, but one which seems the most urgent desideratum for our enhanced understanding of the kindred ties that bound medieval AngloJewry together in a hostile environment. ${ }^{21}$ Meanwhile, it seems clear enough that at least the most substantial Jewish families of thirteenthcentury England were normally small and normally very close-knit. $\mathrm{Dr}$ Cecil Roth's discussion of the evidence for the Oxford Jewry, more impressionistic accounts of other provincial Jewries, and, above all, V. D. Lipman's treatment of the incomparable documentation for Norwich, suggests that, in the latter's words, 'a family of more than three or four

19 Rotulorum originialium abbrevatio (London, 1805-10), 1, pp. 73-6; B. L. Abrahams, 'The condition of the Jews of England at the time of their Expulsion in 1290', TJHSE, 2 (1896), pp. $76-105$.

20 These figures are cired from the draft (June 1991) of the forthcoming report on the Jewbury excavation to be published as York Archaeological Trust $A Y / 12 / 3$. For a preliminary indication of the importance of the site see P. Turnbull, 'Jewbury', Interim Bulletin of the York Archaeological Trust, 9 (1983), pp. 5-8.

21 The reasons why so many English Jewesses bore French rather than Hebraic first names, and why so many of their sons were identified by their mothers' rather than their fathers' names, are only two examples of issues which deserve much further consideration. For a very incomplete list of 'Names of Jewesses in England', see Adler, Jewish Woman, p. 21 ; and cf. the brief account of 'Nomenclature' in R. R. Mundill, 'The Jews in England, 1 272-1 290' (D.Phil. thesis, St Andrews, 1987), pp. xviii-xix. 


\section{Jewish Women in Medieval England}

children must have been a rarity. ${ }^{22}$ Indeed, in the great majority of documented medieval Jewish families it seems difficult to find incontrovertible evidence that a Jewish father and mother had more than two living children; while it is even more noticeable that the copious records of the Jewish plea rolls are more or less totally devoid of references to extant grandparents or even to uncles, aunts, and cousins.$^{23}$ On the basis of this very treacherous if extensive evidence, one must hesitate to be too positive. But it now seems as if the Jewish households of Plantagenet England may often resemble, not too surprisingly, those late twelfthcentury Jewish family units in the Rhineland recently revealed by Professor Kenneth Stow as-in his own words-'small, comprising an average of five souls, and two generational only.' ${ }^{24}$ If so, it seems more likely than not that the great majority of the small, nucleated, urban Jewish households of medieval England, of which there were perhaps rarely more than thirty or forty in any provincial Jewry, were no larger, and conceivably smaller, than those of their Christian neighbours.

Such a possibility, perhaps a little unexpected although not in itself at all startling, may make some well-known features of the history of the medieval Anglo-Jewry easier to explain, but leaves others as inexplicable as ever. How did these groups of tiny, family economic units regulate between themselves the competitive processes of money-lending, upon which one assumes they nearly all depended for their survival? ${ }^{25}$ How could large concentrations of financial capital be safely accommodated, managed, and invested within these often insubstantial nuclear-family businesses? How did a variety of such small, family concerns co-exist within the exceptionally inegalitarian financial regime revealed to us by every royal tallage return of the period, and with the literally colossal fortunes amassed by such great Jewish entrepreneurs as Aaron of Lincoln, David of Oxford, and Bonamy of York? ${ }^{26}$ To those questions, economic

22 Lipman, Jews of Medieval Norwich, p. 47; cf. C. Roth, The Jews of Medieval Oxford - OHS, ns, 9 (1951), pp. 16-45; Dobson, 'Decline and Expulsion', p. 43.

${ }^{23}$ See also the particularly informative accounts of receipts from Jews in the Tower of London between 1275 and 1278 (Cal. Jewish Plea Rolls, 4, pp. 148-94).

$24 \mathrm{~K}$. R. Stow, The Jewish family in the Rhineland in the High Middle Ages: form and function', $A H R, 42$ (1987), pp. 1085-97.

25 This problem is largely unaffected by the recent argument that after 1275 the English Jewry experienced a fundamental 'change from moneylender to credit agent': R. Mundill, 'AngloJewry under Edward 1: credit agents and their clients', TJHSE, 31 ( $1988-90)$, pp. I-21.

26 J. Jacobs, 'Aaron of Lincoln', TJHSE, 3 (1 899), pp. 157-79; Koth, Jews of Medieval Oxford, Pp. 40-9, 87-8, 132-3; Dobson, 'Decline and Expulsion', pp. 45-6. The names of the major Jewish contributors to the tallages of 1221,1223 , and 1225 are now conveniently listed in 


\section{BARRIE DOBSON}

questions upon which a proper understanding of the social structure of the English medieval Jewry must ultimately depend, there still seem no very easy answers. However, it might well be conceded (the argument has now become almost obligatory in the case of Christian women in English towns after the Black Death ${ }^{27}$ that the smaller the household, the more significant, more necessary, indeed, the economic contribution to be made by its female members. Not long ago Dr Judith Bennett claimed that the subordination of the Christian woman in the medieval English countryside was rooted in her household: ${ }^{28}$ by contrast, in the case of the Jewish woman her household was the primary agency of some very real, if admittedly limited, liberation.

Ever since I655, when William Prynne published the second part of his Short Demurrer to the Jewes Long discontinued Remitter into England, from what he called 'the rich unknown Magazine of our generally neglected, slighted precious old records', it has been a commonplace that by associating his wife with him in business the medieval English Jew was unlike his Christian neighbour. ${ }^{29}$ Not quite unlike; for as the late H. G. Richardson once pointed out, Christian money-lenders did the same. However, Richardson's own explanation for the ubiquity of this marital business association between Jews-that it 'facilitated the transfer of debts to the widow or heir on the death of the head of the household'-clearly goes nowhere near far enough. ${ }^{30}$ From the time, at least by the minority of Henry III, that the financial affairs of the English Jewry were firmly integrated into a complex royal governmental machine, it was as axiomatic to the justices as to the officials of the Exchequer of the Jews that a Jewish woman had as much right to resort to that machine as did her husband or her son. Although this 'liberal' practice is readily explicable in terms of the Crown's interest in the recovery of the debts to all of his Jewish subjects, male and female, such complete legal sexual equality remains remarkable-if perhaps slightly less remarkable than the ability of so many Jewish wives to exercise independent business initiatives within

J. Hillaby,'A magnare among the marchers: Hamo of Hereford, his family and clients, 1218 I2S3', THJSE, 31 (1988-90), pp. 30-1.

27 P. J. P. Goldberg, "Female labour, service and marriage in northern towns during the later Middle Ages', $N H, 22$ (1986), pp. 32-5; 'Mortality and economic change in the Diocese of York, 1390-1514', NH, 24 (1988), pp. 42-53.

${ }^{28} \mathrm{~J}$. Bennett, Women in the Medieval English Countryside: Gender and Household in Brigstock before the Plague (Oxford, 1987), pp. 48-64, 198 .

29 W. Prynne, Short Demumer (London, I655-6), pr ii, p. 136.

${ }^{30}$ Richardson, English Jewry, Pp. 44-5. 


\section{Jewish Women in Medieval England}

their households themselves. To state the obvious, it is as a businesswoman that the English Jewess of the thirteenth century tends to be known to us at all. Naturally enough, a few Jewish women managed to remain comparatively distant from their husband's financial affairs. It was discovered, for example, of Avegaye of London, in 1267 , that the wife "had nothing that is not her husband's. ${ }^{31}$ However, even in such a case, the plea rolls of the Exchequer of the Jews make it abundantly clear that a wife might (and often did) negotiate a loan and prepare a bond on her husband's behalf, most obviously in his absence. Indeed, the frequent absences from home of the Jewish male heads of the household, again thoroughly documented in the plea rolls, gave their wives an opportunity not only to carry on a family business while their husbands were away, but also to lend money without their husband's knowledge (like Godenota of Lincoln in I220) or even to falsify documents and forge seals (like Belassez of York in 1277). ${ }^{32}$

More significantly still, it may well have been the female members of the Jewish family who handled the lion's share of the (much neglected) pawnbroking activities of her household. In medieval England, as in other places and at other times, the pledging of chattels for small advances of cash was not a form of business likely to lead to much in the way of permanent record; but its prevalence, and its significance for ChristianJewish relations, certainly deserves more thought than it has usually received.$^{33}$ To take only one example, in $\mathrm{I} 224$ a certain Robert Cristfinesse of Chichester borrowed 3 s. on the deposit of a bowl of mazer-wood and two silver buckles. However, he then endured the mortification of seeing the coins in question confiscated by the town bailiff on the grounds that they were clipped: only for that reason do we know that the loan had been made by Bona, wife of the Jew Diaia, on this occasion allegedly in her husband's presence and at his command. ${ }^{34}$ For many of her closest Christian neighbours, one may fairly safely surmise that the Jewish woman of pre-Expulsion England (like so many of her successors in years to come) was seen less as a subversive threat to belief, even less in her legendary role as a sinister seductress of young Christian clerks, but rather as a useful if hazardous source of credit in rimes of trial.

31 Cal. Jewish Plea Rolls, 1, pp. 145-6; cf. pp. 200-1.

32 Ibid., I, Pp. 43-4; CCR, 1272-79, p. 487.

${ }^{33}$ For the plausible suggestion that pledging of chattels to the Jews was not only very common indeed, but led them into contact with 'all classes of society, from clergy and knights down to thieves', see Richardson, English Jewry, pp. 76-8.

34 Rigg, Select Pleas, pp. 8-9. Cf. ibid., p. I r; Cal. Jewish Plea Rolls, 1, p. 73, for examples of Jewesses being accused of coin-clipping. 


\section{BARRIE DOBSON}

Such themes might be elaborated at length; but it may be more important to summarize a few of the legal rights and obligations customarily enjoyed by the thirteenth-century Jewess but usually denied, in practice if not in theory, to her Christian counterpart. As Michael Adler pointed out sixty years ago, the Jewish woman could hold landed property, including, of course, town houses and tenements, with no lord intervening between herself and the king. ${ }^{35}$ She could also manage and control both a local and a national money-lending business, usually, no doubt, in partnership with her husband or her sons, but on frequent occasions in her own right too. The Jewish wife or widow was able to prosecute both Jews and Gentiles in the royal courts, most often before the Justices of the Jews but not exclusively so. ${ }^{36}$ She had the right to find sureties and mainpernors when impleaded at law herself; and she could similarly act as surety for others, including an imprisoned husband. She was entitled to lease urban property for rent, with the incidental result that, according to Cecil Roth, the Jewesses of medieval Oxford may have been among the very first student landladies at the new university there ${ }^{37}$ Finally, in this highly incomplete list, the Jewish woman could lend money, as has been implied, upon the security of estates, rents, and chattels of all types, not excluding such considerable collections of grammar and legal manuscripts as those (including a copy of the Institutes valued at $4 \mathrm{~s}$. Od.) still in the possession of Belaset and Hittecote, Jewesses of Oxford, when they were converted to Christianity early in the reign of Edward $\mathrm{I}^{38}$ No historian who has wrestled with the admittedly tantalizing evidence in this field has ever doubted the bewildering variety of such traffic: it would be hard to exaggerate the extent to which, despite official ecclesiastical prohibition, Bibles, chalices, church ornaments, and other items central to the practice of the Christian religion were regularly pledged to the members (often female) of the English provincial Jewries. ${ }^{39}$

3s For some unusually explicit examples of the purchase and sale of town houses by several Jewesses of Canterbury in the early thirteenth century, see Adler, 'The Jews of Medieval Canterbury', in Jews of Medieval England, pp. 68-9, 72.

${ }^{36}$ See Comitissa of Gloucester's explicit declaration before the Justices of the Jews in 1220 that she would 'prove as Jewess against Jew' the conspiracy whereby her late husband had been thrown to his death from the walls of Gloucester Castle: Cal. Jewish Plea Rolls, I, p. 45; cf. Hillaby, Worcester Jewry, pp. 91, 100; and for examples of Jewesses' appearances before the Beth Din, see Adler, 'Jews of Medieval Canterbury', p. 73; M. D. Davis, ed., Shetaroth: Hebrew Deeds of English Jews (1180-1290) (London, 1888) [hereafter Shetaroth], Pp. 5, 29, 40.

37 Roth, Jews of Medieval Oxford, pp. $136-50$.

${ }^{38}$ Rigg, Select Pleas, p. I 14 .

${ }^{39}$ Ibid., p. lv; Roth, History of Jews, p. 105; Richardson, English Jewry, pp. 76-7, 187-8. 


\section{Jewish Women in Medieval England}

The diversity of economic activity on the part of the medieval Jewish woman was, however, never to be more manifest than when she became-as she so often did-head of her own household. In other words, it was as widows that the more substantial Jewesses of Angevin and Plantagenet England are unquestionably revealed at their most wealthy, most influential, and, at least in some senses of the word, most liberated. Here again there exists an obvious analogy between the feminine elite within both Christian and Jewish sociery: for it was as a widow that a thirteenth-century Christian heiress like Lady Isabella de Fortibus (to take perhaps the most relevant contemporary example) was at her most formidable too, during her long years of widowhood from 1260 to $1293{ }^{40}$ Nevertheless, there can be no doubt at all that the legal and public status of the Jewish wife and widow was buttressed by conventions, customs, and practices largely or completely denied to her Christian counterparts. Not all of these advantages derived from radically different legal practices between the two religious persuasions. One of the most important, if prosaic, reasons for the English Crown's readiness to recognize the rights of a bereaved Jewess to her due share of her husband's estate was its disinclination to see the excessive fragmentation of a complex financial business in which it had its own interests. Accordingly, and although it was usual for the royal government to appropriate the third part of a deceased Jew's estate 'ad opus regis' soon after his death, his widow was emphatically not likely to be deliberately driven into complete penury forthwith. ${ }^{41}$ With the solitary exception of Licoricia of Winchester's remarkable payment of no less than 5,000 marks in 1244 , itself a tribute to the quite exceptional wealth of her deceased husband, David of Oxford, the fines levied on Jewish widows to secure their husband's chattels were usually considerably less than the financial appetites of the Plantagenet monarchy might lead one to expect. ${ }^{42}$

As the English monarchy, its own profits apart, always expected its Jewish communities to be largely self-regulatory, it was no doubr most important of all that Jewish matrimonial law and custom protected the

40 Complete Peerage, 12 vols (London, 1910-59), 1, pp. 355-6; N. Denholm-Young, 'The Yorkshire Estates of Isabella de Fortibus', Yorkshire Archaeological Journal, 31 (1934), pp. 389-420; Seignorial Administration in England (Oxford, 1937).

4I Shetaroth, p. 60; Adler, 'Jewish Woman', p. 19.

42 Ibid., pp. 39-40; Roth, Jews of Medieval Oxford, pp. 55-6. More characteristic of the fines imposed upon Jewish widows to receive delivery of their husbands' moveables and houses is the 400 marks paid by Floria on the estate of Master Elias of London: Rigg, Select Pleas, pp. $13 \mathrm{I}-2$; cf. ibid., pp. 35, 42,6 1 . 
interests of Jewish widows, and, indeed, of Jewish wives and daughters too, much more scrupulously than Christian marriage conventions safeguarded those of their Gentile neighbours. Naturally enough, the realities of Jewish marriage practice in thirteenth-century England can only be observed through a glass very darkly indeed; but, at the least, sufficient scraps of incidental information survive on this side of the Channel to make it clear that the English Jewess was expected to live her life within behavioural codes familiar enough to readers of Rashi and his successors in northern France. ${ }^{43}$ In principle, such codes-not, of course, without their own inherent contradictions-naturally rarely envisaged anything but female subordination to the male head of the household; but in practice that subordination was often qualified, most notably by the recognition that 'Our Women transact business these days', and that in extreme situations divorce could be a viable alternative to marital disharmony. ${ }^{44}$ More specifically, it is well known that Jewish marriage customs placed more practical and rational emphasis upon arrangements for the bride's (and future widow's) well-being than was likely to be encountered by most Christian women at their equivalent rites of passage.

Such differences seem, in fact, to be reflected in the contrast to be observed between the celebration of Christian and Jewish weddings themselves during the thirteenth century. On the basis of admittedly highly impressionistic evidence, medieval Jewish weddings show every sign of having been more spectacular, more lavish, and, above all, better attended affairs than those of Christian townswomen during the period. In the summer of 1255 , for example, it was the presence of a so-called 'unusually large concourse' of Jews attending a great wedding in Lincoln which encouraged the fabrication of that most fatally influential of all English blood-libel allegations, the supposed martyrdom of little $\mathrm{St}$ Hugh'.5 However, the locus classicus in this field is undoubtedly the wellknown Jewish wedding allegedly celebrated within the comparatively

${ }^{43}$ Rabinowitz, Jews of Northern France, pp. I 40-57; Agus, Urban Civilization, pp. 554-95. For the argument (quite probably applicable to thirteenth-century England) that diametric oppositions between the elite culture of Jews and Christians could nevertheless coexist with similar perceptions of marriage, see E. Cohen and E. Horowitz, 'In search of the sacred: Jews, Christians, and rituals of marriage in the later Middle Ages', Journal of Medieval and Renaissance Studies, 20 (1990), pp. 225-49.

4 For 'the most famous divorce of the period', of Muriel of Oxford from her husband David, see Adler, 'Jewish Woman', pp. 28-9; cf. M. D. Davis, 'An Anglo-Jewish Divorce, A.D. 1242', $J Q R, 5$ (1893), pp. I 58-65; Rabbinowitz, Jews of Northern France, p. I6 3.

45 Matthew Paris, Chronica Majora, 7 vols, RS (1872-83), 5, pp. 516-19; Rigg, Select Pleas, pp. $x x x-x x x i i$. 


\section{Jewish Women in Medieval England}

small and obscure Jewry of Hereford in 1286 , only four years before the Expulsion. Our knowledge of that event derives exclusively from Bishop Richard Swinfield of Hereford's indignation ('dicto horrendum est') that so many Christian acquaintances of the Jewish couple had accepted their invitation to be present at an unprecedentedly magnificent series of festivities, complete with 'displays of silk and cloth of gold, an equestrian procession, stage plays [unspecified, alas], sports and other acts of minstrelsy'.46 Although this Jewish wedding at Hereford in I 286 may be rather brittle evidence on which to support the case, as is sometimes done, for deep personal harmony between Christians and Jews at the local level during the last years of medieval Anglo-Jewry, it seems to reveal-not a little surprisingly-that a late thirteenth-century English bishop positively expected a Jewish wedding to be highly attractive to Christians.

For the well-connected Jewish bride-whose marriage was in any case quite as likely to be arranged by her father as was that of her Christian counterpart-it was less her wedding than her Kethubah or betrothal contract, together with her dowry from her own family, which safeguarded her long-term future. ${ }^{47}$ Fortunately enough, a few such contracts, so crucial to the welfare of the Jewish wife and widow, survive in English archives; and references to several more are probably still to be discovered. ${ }^{48}$ Perhaps the most informative English example, preserved among the muniments of Westminster Abbey, records how at Lincoln in I 27I, after approval by a duly constituted Beth Din, a Jewess called Belassez promised a dowry of twenty-marks value to the future husband, Aaron, of her daughter Judith. Among Bellasez's other gifts to Aaron the most intriguing is a Hebrew copy of the twenty-four books of the Old Testament: as the manuscript in question is said to have been written on duly punctuated and embellished calf-skin, the interesting implication here may be that the bridal couple would in due course read this Bible together. For his part, the bridegroom, Aaron, undertook to provide his prospective bride, Judith, with her Kethubah, or marriage settlement proper, a cash sum totalling $\oint^{100}$, as 'is the custom of the Isle'.49 Not all

${ }^{46}$ Registrum Ricardi de Swinfield episcopi Herefordensis, A.D. 1283-1317, ed. W. W. Capes, CYS, 6 (1909), pp. 120-2. The local context of this wedding is interestingly discussed in Hillaby, 'Magnate among the Marchers', pp. 74-5.

47 Abrahams, Jewish Life, pp. 186-2 I0; T. and M. Metzger, Jewish Life in the Middle Ages (New York, 1985), pp. 227-33, including a photograph of the only illustrated Kethubah (from Krems in Austria, dated I 392 ) known to have survived from the medieval West.

48 Shetaroth, pp. 32, 43-6, 94 .

49 Ibid., pp. 298-302, tr. in Adler, 'Jewish Woman', pp. 43-5. 


\section{BARRIE DOBSON}

Jewish brides did in the event secure so valuable a Kethubah as the standard Eroo; but several received an even more generous settlement, certainly comparable with the maritagium or dower enjoyed by their Christian equivalents. Usually more valuable still were the gifts of the bride's father to herself and her new husband: it was apparently by no means unusual for the Jewish bride to receive a gift of one or more houses at the time of her marriage. ${ }^{50}$ Generous endowments of this type from her father, as well as her husband, probably help to explain the important issue of how several Jewish wives could gain access to sufficient capital to begin credit operations in their own right during the early years of their marriage.

However, the main objective of the Kethubah, as of a Christian heiress's dower, was to protect the Jewish wife's position at the time of her husband's death. On all the evidence available, this is certainly what it served to do. Naturally enough, the amount and proper assignment of the Kethubah could lead to dispute between Jewish families themselves; but there is abundant evidence among their plea rolls that the Justices of the Jews rapidly came to the aid of widows whose claims to dower were being disregarded or subjected to illegal distraint. ${ }^{51}$ Not surprisingly, therefore, several widows of the more substantial members of the English Jewry were eventually in a position to retire from business and household cares, probably not a future available to many Christian townswomen. A particularly well-documented example of this practice is afforded by a certain Gentil of Norwich, who, in I25I, had surrendered her late husband's estate to her three sons in return for a variety of concessions, ranging from a maintenance allowance of five marks a year to the quiet and exclusive possession of a large house in Mancroft Street. ${ }^{52}$ Many, and probably most, Jewish widows, however, sought to maintain and even augment their deceased husbands' business concerns, with the inevitable result that they thereby enhanced their attractiveness to an aspiring Jewish male. Here again both Jewish and Christian legal convention protected the Jewish widow a good deal more actively than her Christian counterpart. A particularly instructive example of a common syndrome is provided by the later career of Milla of Royston, who had lost her husband at the hands of Simon de Montfort's adherents in the early 1260 s. She was immediately

30 Cal. Jewish Plea Rolls, I, p. 192; Shetaroth, p. I 36.

51 For the principle thar Jewesses 'ought not to be distrained after the death of their husbands in the dowers they have of tenements, goods and chattels for any fines due from their late husbands', see CCR, 1279-88, p. 47; Adler, 'Jewish Woman', p. 30.

32 Lipman, Jews of Medieval Norwich, pp. $137-40$, provides an exceptional insight into the marriage relationships which characterized this 'typical Jewish middle-class family'. 


\section{Jewish Women in Medieval England}

thereafter courted by a Master Samuel of Bolum, who later claimed that 'by reason both of contract and commerce between them' she had become his wife. However, Milla appealed to a group of rabbis, who had no hesitation, like many other Jewish authorities in similar circumstances, in pronouncing this alleged second marriage null and void: they accordingly left Milla in full possession of her first husband's property and directed Master Samuel to leave her in peace thereafter. ${ }^{53}$ On the limited evidence available, Jewish widows also seem to have been even more successful than Christian ones in petitioning the Crown either not to marry a particular individual or not to marry at all..$^{54}$ Fear of disparagement, one might well suppose, was quite as powerful an emotion among well-born Jewesses and their families as it was in aristocratic Christian circles: here is one of several indirect indications that Jewish concepts of status were not unaffected by the principles and practices of contemporary Christian knighthood and inheritance.

However, the main conclusion seems obvious enough: all in all, it was considerably easier for a Jewish woman to resist remarriage than it was for her Christian neighbour to do so. Nor was it for that reason alone that the figure of the Jewish widow seems to move especially prominently into the centre of the scene the closer one approaches Edward I's final solution of I 290. As Jewish husbands, sons, and brothers were subjected to ever more severe and of ten murderous harassment during the 1270 s and 1280 , so their morhers and sisters often become increasingly conspicuous, in taxation and other records, among the last survivors of medieval AngloJewry. ${ }^{55}$ Nor is it likely to be a coincidence that the two best-documented and almost certainly most wealthy Jewesses known to medieval England belonged to this last doomed generation. Admittedly neither Henna, widow of Aaron of York, nor Licoricia of Winchester, widow of David of Oxford, lived quite long enough to see the final expulsion of all their coreligionists from the England they had made their homeland.$^{56}$ However,

53 Cal.Jewish Plea Rolls, I, pp. 152, 1 54, 163 ; Stokes, Studies in Anglo-Jewish History, p. 164.

$54 \mathrm{~J}$. Jacobs, The Jews of Angevin England: Documents and Records (London, 1893), pp. 28, 44-5, 332; Stokes, Studies in Anglo-Jewish History, p. 128.

35 PRO, E. IO1, 249/22; Cal. Jewish Plea Rolls, 4, pp. 16-17, 139-94; Hillaby, 'Worcester Jewry', Pp. 106-1 3. Proof that almost 300 Jews were hanged for alleged currency offences in $1278-9$ is now provided by Z. E. Rokeah, 'Money and the hangman in late thirteenth-century England: Jews, Christians and coinage offences alleged and real', TJHSE, 31 (1988-90), pp. 83-IO9.

s6 Henna, regularly called widow of Aaron of York throughout the 1270s, seems to have died soon after she received-in 1280-a royal licence (as Henna, daughter of Leo de Eboraco and mother of Elias) to sell one of her houses in Coney Street: CPR, 1272-81, p. 380 . Licoricia's 
the careers of both these women would still repay more attention than they have received: for they provide not only the best commentary upon how wealthy and influential a thirteenth-century Jewess could become, but also illustrate to perfection the fragility of that wealth and influence during the lingering decline of the medieval English Jewry in its melancholy penultimate years.

Henna, daughter of Leo de Eboraco and therefore a member of the most distinguished Jewish family in early thirteenth-century York in her own right, first becomes prominent in surviving records as the wife of Aaron, regarded by Matthew Paris as both the richest and ultimately the most unfortunate Jew of Henry III's England. ${ }^{57}$ Although husband and wife were increasingly engaged in property transactions together during the last period of Aaron's life, it was only in the dozen or more years after his death in 1268 that Henna fully demonstrated her own business acumen and stamina. One of the few medieval English Jewesses known for certain to have been able to write in Hebrew, until her death in or about $\mathrm{I} 280$ she pursued a relentless campaign designed to preserve (which in the end it failed to do) the shattered remnants of her husband's once phenomenal business empire. ${ }^{58} A$ not dissimilar attempt to preserve the no longer preservable seems to characterize the final stages of the remarkably picaresque life of Licoricia of Winchester. Born in that city about I220, Licoricia's turbulent career illustrates the special advantages of being widowed not once but twice, especially if one's second husband was a figure as substantial as David of Oxford, whose estate was subjected to an almost unparalleled royal relief of 5,000 marks on his death in $1244 .{ }^{59}$ The central figure in the most notorious and controversial Jewish divorce case in thirteenth-century England, the last twenty years of Licoricia's life were most notable for the aggression with which she pursued her Christian debtors, the hostility she aroused among her fellow Jewesses at Winchester, and her remarkable powers of survival. After several periods of imprisonment, sometimes on false accusations of theft, Licoricia was eventually murdered under highly mysterious circumstances in 1277 , two years before Benedict, the most successful of her five sons, was hanged

murder was investigated by a specially appointed Winchester jury in 1277 : Cal. Jewish Plea Rolls, 3, pp. 248, 293.

57 Cal. Jewish Plea Rolls, 1, pp. 18 I, I 86, 210-1 1; Marthew Paris, Chronica Majora, 5, p. 136 ; Adler, 'Aaron of York', in Jews of Medieval England, pp. 127-73.

58 Cal. Jewish Plea Rolls, I, p. 270; 3, pp. 31, 78, 102, 156, 202, 244, 278; Dobson, Jews of Medieval York. pp. 43-4.

59 Roth, Jews of Medieval Oxford, pp. 54-7; see n. 42, above. 


\section{Jewish Women in Medieval England}

in the course of Edwardian England's greatest outburst of collective murder. ${ }^{60}$

Although Licoricia, like her son, was almost certainly killed by Christian hands, her remarkable career may serve to introduce some of the ambiguities inherent in the final theme of this paper, the mysterious relarionship between thirteenth-century Jewish women and the Christian society around them. That this relationship was often one of bitter irony is clear enough. There is considerable circumstantial evidence, for example, that until her death Licoricia herself owed much of her economic resilience, exemption from taxation, and indeed sheer ability to survive to the personal protection and at times patronage of no less a person than King Henry III himself.' ${ }^{61}$ The career of Bonamicus of York, that royal financier who in 1290 left the service of Edward I for that of Philip the Fair, also shows that monarchs and prelates who fulminated against the usurious practices of their Jewish subjects were at times perfectly ready to welcome the most successful Jewish money-lenders into their own entourage. ${ }^{62}$ In the very different and much smaller world of the English provincial town, it is not hard to find similar ironies in play. Shortly after the great York massacre of 16 March 1190 , the well-informed chronicler William of Newburgh went out of his way to observe that 'the nobilitas et cives graviores of the town, fearing the dangers of the king's reaction, had cautiously declined to take part in such madness. ${ }^{63}$ Recent accounts of certain thirteenth-century provincial Jewries, notably perhaps Dr Derek Keene's survey of the Jews of medieval Winchester, have also tended to advance the case, however marginally, for a reasonable degree of harmonious co-operation-if not necessarily of friendship-between Jewish families and the more substantial Christian townsfolk who were literally their neighbours. ${ }^{64}$

In the nature of the evidence, amicable relationships between Jewish

${ }^{\infty} \mathrm{H}$. P. Stokes, 'A Jewish family in Oxford in the thirteenth century', TJHSE, 10 (1925), pp. 193-206: Adler, Jews of Medieval England, p. 92.

"Henry III's personal intervention on Licoricia's behalf in her complex plea against the Charlecote family in 1253 is well documented in Rigg, Select Pleas, pp. 19-27. For the 'inexplicable absence' of Licoricia from the tallage of $1239-42$ see R. Stacey, Politics, Policy and Finance under Henry III, 1216-1245 (Oxford, 1987), p. 151.

62 Dobson, 'Decline and Expulsion', pp. 44-6; cf. Chazan, Medieval Jewry in Northern France, pp. $183-4$; Roth, History of Jews, pp. 56, 274 (for the best-known case of personal patronage of a Jew by a member of the English royal family, Richard of Cornwall).

${ }^{63}$ Chronicles of the Reigns of Stephen, Henry II and Richard I, RS, 82 (I884-9), I, Pp. 322-4; cf. the translation by Dr P. P. A. Biller in Clifford's Tower Commemoration (York, 1990), p. ${ }^{8}$.

ot D. Keene, Survey of Medieval Winchester - Winchester Studies, 2 (Oxford, 1985), pp. 76-9. $385-6,324-5,384-7,1034-5$; Hillaby, 'Hamo of Hereford', pp. 74-5. 
women and Christian families in thirteenth-century English towns is not, however, likely to be well reflected in surviving plea rolls. According to Henry III's well-known provisions sent to the Justices of the Jews on 3 I January I 253, the only purpose of female as well as male Jews, from the hour of their birth onwards, was to 'serve us in some way': no Christian man or woman was 'to serve any Jew or Jewess, or to eat with them or remain in their houses'. ${ }^{65}$ Perhaps the most interesting indication that such conditions of complete apartheid did not, in fact, apply, either before or after 1253 , are the occasions when Jewish and Christian families are known to have sheltered each other's chattels. During the last three threatening decades of the medieval English Jewry's existence, it was obviously not at all uncommon throughout the country for alarmed Jewish families to deposit their valuables, their linen, and their kitchen equipment for security's sake under the floor, under the straw, or under the beds of their Christian acquaintances. Only when such activities led to mutual recrimination and eventually to litigation is one likely to discover, as in a Surrey case of 1266 , that according to a certain Matilda Pepper, Aaron the Jew had come 'to her house and hid certain goods under the straw' while she was at church. More frequent was the situation illustrated by a London plea of 1267 , where it was agreed by both parties that Isaac of Warwick and his wife, Ivetta, had deposited for safe keeping with Hugh de Dernestall and his wife not only an expensive vestment, but a casket of jewels, six silver spoons, a bowl of mazer-wood, and other valuables. ${ }^{66}$

In this, yet again ambiguous, display of at least a modicum of trust between some Jewish and some Christian families, women-on both sides of the divide-are often likely to have been more involved in the safe keeping of chattels than their menfolk. The same generalization applies much more obviously to one of the most notorious issues presented by medieval Jewish settlement in western Christendom, the consequences (primarily sexual) which it was feared might follow from the employment within one's household of female servants-and especially wet-nursesfrom outside one's own religion. It has of ten been argued, almost certainly correctly, that the very frequency of English royal and ecclesiastical legislation on the subject is itself an indication of its ineffectiveness: as late as 1273 , for example, the presence of a Jewish nurse in the house of a

${ }^{65}$ Rigg, Select Pleas, p. xlix.

o6 Ibid., pp. 33, 38, 108-9. Such cases can sometimes be hard to distinguish from instances of Christian males borrowing from Jews on the security of items of household equipment or of their wife's clothing (see CCR, 1261-64, pp. 19-20). 


\section{Jewish Women in Medieval England}

certain Christian, of London' seems to have caused no surprise at all. ${ }^{67}$ Rather more surprisingly, at the time of her murder in 1277 , Licoricia of Winchester's own handmaid was herself a Christian, who died with her mistress. ${ }^{68}$ On the whole, official attitudes were usually much more hostile to the prospects of Christians serving in Jewish households (most probably 'as nurses of children, bakers, brewers, and cooks') than vice versa; and in practice, too, it seems to be the case that there were more Christians working as domestic servants for Jews than Jewish women acting as nurses for Christians. ${ }^{69}$ Comparatively few such offences, however, are known to have been brought to trial; and in any case thirteenth-century bishops, like some modern historians, probably exaggerated the importance of these and analogous daily contacts between Christian and Jewish women. On the whole, and with due allowance made for the dangers that such delicate issues might be suppressed from the record, sexual relations between Christians and Jews surface in the plea rolls comparatively rarely; even in the single most apparently circumstantial case, where Isabel of Lockerley charged a Jew from Windsor with assault in the street, followed by rape in his own home, the jury of twelve Christians and twelve Jews found the case to be without substance. ${ }^{70}$

What little documentary evidence survives therefore fails to confirm (although no doubt it does little to disprove) the hypothesis that in thirteenth-century England a stereotyped image of the Jewess as an insidious femme fatale, luring young Gentile males into apostasy, had already begun to inform the prejudices of her Christian contemporaries. However, an even more important question to raise within the context of 'Christianity and Judaism' is whether there is the slightest hope of discovering how the Jewish women of thirteenth-century England responded to the Christian Church within whose interstices they lived their always precarious lives. Although that question too is unanswerable, except in the vaguest of terms, the cumulative impression left by the surviving records is undoubtedly one of Jewish female religious resilience rather than of complete demoralization. Here perhaps the most severe test

${ }^{67}$ The nurse in question later migrated to Normandy with her ward (Rigg, Select Pleas, p. 75).

68 Cal. Jewish Plea Rolls, 3, p. 293.

69 CCR, 1234-37, p. 13; Rigg, Select Pleas, pp. xlviii, lv; The Life and Miracles of St William of Norwich by Thomas of Monmouth, ed. A. Jessopp and M. R. James (Cambridge, 1896 ), p. 89. The long-standing canonical denunciation of unduly close propinquity between Christian and Jew reaches its English climax with Edward I's I 275 Statute of Jewry, forbidding Christians to live in Jewish households: see J. A. Watt, 'The Jews, the law, and the Church: the concept of Jewish serfdom in thirteenth-century England', SCH.S, 9 (1991), p. 163.

70 Rigg, Select Pleas, p. I04. 
was presented by the various campaigns to convert the king's Jews and Jewesses to Christianity, campaigns pursued-as far as we know-only intermittently during the reign of Henry III, but much more intensively during the so-called Edwardian experiment of $1275-90 .{ }^{71}$ However, there will never be a serious hope of knowing how large a proportion of the thirteenth-century English Jewesses abandoned their faith as a result either of Dominican sermons, local persecution, or urgent economic considerations; and it is almost as difficult to decide whether Jewish women were marginally more resistant-as they quite conceivably were-to the attractions of conversion than their male relatives. It would be a brave act to make much of the fact that of the ninety-six Jewish converts apparently lodged in the Domus Conversorum in Chancery Lane between 1280 and 1308 , fifty-two were women and forty-four were men. ${ }^{72}$ It seems considerably more revealing that of the once notorious fifteen relapsed Jewish apostates of London, brought to light in 1283 during the course of one of Archbishop Pecham's most persistent witch hunts, no less than thirteen were women. ${ }^{73}$

Much more certainly it is absolutely clear that under the pressure to convert to Christianity Jewish wives and Jewish husbands of thirteenthcentury England sometimes, perhaps of ten, took quite different decisions. Would it be too facile, for instance, to interpret the apostacy of Joiette, wife of Solomon fil' Lumbard of Cricklade, who in I 268 'convertit ad fidem Christianam' without her husband, as a manifestation of the Jewish female independence, however qualified, which has been one of the themes of this lecture? ${ }^{74}$ Perhaps not; for in a cause célèbre at Canterbury in I235 the Jewess Chera not only defied legal expectation by refusing to follow her husband into the Christian faith, but continued to claim her house as part of her original marriage settlement. ${ }^{75}$ It is yet another tribute to the status of the Jewish woman (and future mother) that her conversion to the Christian faith was, apparently, often more fiercely opposed by her

"It seems less than clear whether Edward l's famous mandate of 1280 instructing his sheriffs to ensure that Jews should attend the new conversionary sermons to be preached throughout the realm by the Dominican friars were meant to apply to women as well as to men: see CPR, 1272-81, p. 356; D'Bloissiers Tovey, Anglia Judaica (Oxford, 1738), pp. $215-16$.

72 Adler, Jews of Medieval England, pp. 350-2.

${ }^{73}$ F. D. Logan, 'Thirteen London Jews and conversion to Christianity: problems of apostacy in the I 280 s', $^{\circ}$ BIHR, 45 (1972), Pp. $216,227$.

74 Rigg, Select Pleas, pp. 42-3 (confirming that female converts to Christianity forfeited their bonds to the Crown not to their husbands).

75 Adler, Jews of Medieval England, pp. 67-8. 


\section{Jewish Women in Medieval England}

community than that of her husband or son. The most dramatic example of such opposition is provided by the well-known story of Juliana of London, who not long after her conversion to the Christian religion in 1274 was kidnapped by nine Jews (four of them women) from a house in Coleman Street. Before the Jews smuggled Juliana out of the country by means of a ship, which was finally driven back to Sandwich, she was subjected to intense pressure to revert to Judaism: according to Juliana's possibly suspect testimony, a Jewish widow named Antera even went so far as to fasten a cord around Juliana's neck and threaten to hang her 'if she would not abjure the Christian faith and return to their disbelief ${ }^{\prime 76}$

Jewish women of the 1270 s and 1280 s could, in other words, react to the possibility of Christian conversion in very different ways, and not necessarily always passive ways. How could it be otherwise? Since the days of William Prynne, Edward I's ejection of his Jews from England in 1290 (in Cecil Roth's words, 'the first general expulsion of the Jews from any country in the medieval period') has been made to serve many different models: is it altogether a coincidence, to take a recent example, that the Jews were expelled en masse from England at that very point of time which witnessed (as we are currently being informed by the CNRS) le genèse de l'état moderne?"7 Nor would anyone wish to deny that in thirteenth-century England, as in the very different world of the late medieval Mediterranean, it was the profound differences in the economic forces shaping the development of the Jewish and Christian communities which played the primary role in creating such remarkably contrasting roles for the family and the female. ${ }^{78}$ However, the experience of the Jewish women of Plantagenet England is nothing if not a demonstration of how the economic and religious influences upon their lives were inextricably intertwined. The reasons for Edward I's banishment of the Jews from England in I 290 will no doubt always be a contentious matter; but there can at least be no doubt, to end with the bitter argument from which thirteenth-century Jewish women could

76 London, PRO, E. 9, $4 / 17$, memb. I2d; Cal. Jewish Plea Rolls, 2, pp. 209-10; 3, pp. 18 , $4 \mathrm{I}, \mathrm{II}$ I.

7 Roth, History of Jews, p. 9o; J. Cohen, The Friars and the Jews: The Evolution of Medieval AntiSemitism (Cornell, 1982), Pp. I 3-16, 242-64; L'État moderne: genèse: bilans et perspectives (Actes du Colloque tenu au CNRS à Paris. 19-20 September 1989), ed. J.-P. Genet (Paris, 1990), pp. $7-13,26 \mathrm{I}-8 \mathrm{I}$.

78 G. Todeschini, 'Families juives et chrétiennes en Italia à la fin du moyen âge: deux modèles de développement economique', Annales, 45 (1990), pp. 787-817; S. D. Goitein, A Medilerranean Society: The Jewish Communities of the Arab World as portrayed in the Documents of the Cairo Geniza, III, The Family (Berkeley, 1978). 


\section{BARRIE DOBSON}

find no escape, that expulsion, like persecution, is likely to be the result of a Christian failure to convince-as well as a more profound failure to understand.

Christ's College, Cambridge 